DOI:10.22337/2587-9618-2019-15-4-83-87

\title{
ANALYSIS OF COMBINED PLATES WITH ALLOWANCE FOR CONTACT WITH ELASTIC FOUNDATION
}

\author{
Elena B. Koreneva \\ Moscow Higher Combined-Arms Command Academy, Moscow, RUSSIA
}

\begin{abstract}
The paper covers the problems of combined plates with circular base and consisting of a few sections with different laws of thickness variation. Analytical methods of analysis of similar structures are not yet developed. The present work suggests the analytical method for solving of the stated problems, the contact with the elastic subgrade is also considered. The above-mentioned approach is shown on the example of the analysis of the bottom of the cylindrical reservoir, resting on the elastic subgrade. The inner part of this construction is represented by the ring plate of variable thickness which increases along the direction from the internal boundary. The outer part is represented by the ring plate of the constant thickness. The influence of the elastic basis and the upper part of the reservoir is taken into consideration. The solutions for stresses and deflections of the combined plate are given in closed form in terms of Bessel functions. The conditions of the plate's sections conjugation are fulfilled.
\end{abstract}

Keywords: combined plates, bottom of the reservoir, Bessel functions

\section{РАСЧЕТ КОМБИНИРОВАННЫХ ПЛИТ С УЧЕТОМ ИХ КОНТАКТА С УПРУГИМ ОСНОВАНИЕМ}

\author{
E.Б. Коренева \\ Московское высшее общевойсковое командное орденов Жукова, Ленина и Октябрьской Революции \\ Краснознаменное училище, г. Москва, РОССИЯ
}

\begin{abstract}
Аннотация: В работе изучаются комбинированные плиты, состоящие из двух или нескольких участков с различными законами изменения толщины и имеющие в плане круговую форму. Аналитические методы для расчета подобных конструкций практически еще не разработаны. Ниже предлагается аналитический подход к решению подобных задач, также производится учет контакта изучаемой конструкции с упругим основанием. Подобная методика подробно излагается на примере рассмотрения расчета днища цилиндрического резервуара. Внутренняя часть этой конструкции представляет собой кольцевую плиту, толщина которой увеличивается по направлению от внутреннего контура, наружная часть представляет собой плиту постоянной толщины. Производится учет влияния податливого основания и действия веса верхней части резервуара. Решения для перемещений и усилий внутренней и внешней частей комбинированной плиты получены в замкнутом виде и выражены в функциях Бесселя. Выполняются условия сопряжения отдельных участков.
\end{abstract}

Ключевые слова: комбинированная плита, днище резервуара, функции Бесселя

\section{INTRODUCTION}

The work considers analytical calculation of combined plates with circular base and consisting of several sections with different laws of thickness variation. Their thickness may be increasing or decreasing in the direction from the plate's center to the outer boundary. The material of the plates under study is isotropic or orthotropic. The separate sections of the men- tioned constructions may be made from different materials with various physical characteristics. In the places of the sections conjugation the construction remains continuous. However, in some cases the plates' thickness can have the break of continuity in these positions. The analytical methods of the such constructions computation are in practice not yet developed. The present work covers this lacuna. As an example we will consider the work of the bottom of the 
cylindrical reservoir. The bottom is represented by a ring plate, resting on an elastic foundation and consisting of the two sections. The inner part has the variable thickness increasing in the direction to the external boundary. The outer part of the plate has the constant thickness (Figure 1). The elastic foundation properties are described by Winkler's model.

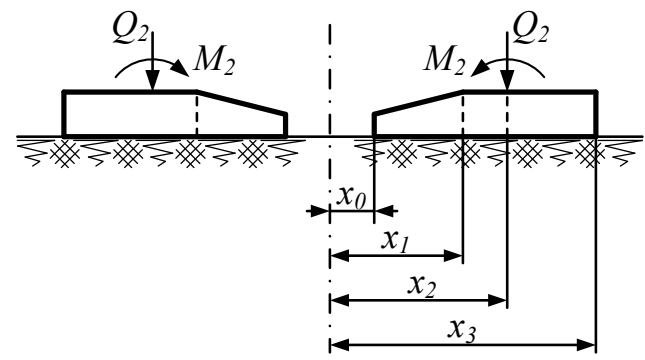

Figure 1. The combined plate on elastic foundation.

The coefficients of foundation under the inner and the outer parts of the plate can be both as different or identical. The loads caused by the upper part of the structure are distributed along the concentric circles. Let us assume that the load is applied to the outer part of the plate and the bottom of the reservoir is made from the isotropic material.

\section{THE COMPUTATION OF THE INNER PART OF THE CONSTRUCTION}

Let us consider the work of the inner part of the bottom of the cylindrical reservoir when $x_{0} \leq x \leq x_{1}$, which is represented by a ring plate with varying thickness, resting on an elastic Winkler's foundation. The construction is subjected to an action of the axially symmetric loads. The differential equation describing the similar plate bending has the following form:

$$
\begin{gathered}
D\left[\frac{d^{4} w}{d r^{4}}+\frac{2}{r} \frac{d^{3} w}{d r^{3}}-\frac{1}{r^{2}} \frac{d^{2} w}{d r^{2}}+\frac{1}{r^{3}} \frac{d w}{d r}\right]+ \\
+\frac{d D}{d r}\left[2 \frac{d^{3} w}{d r^{3}}+\frac{(2+\sigma)}{r} \frac{d^{2} w}{d r^{2}}-\frac{1}{r^{2}} \frac{d w}{d r}\right]+ \\
+\frac{d^{2} D}{d r^{2}}\left[\frac{d^{2} w}{d r^{2}}+\frac{\sigma}{r} \frac{d w}{d r}\right]+c_{1} w=q,
\end{gathered}
$$

where $D$ - cylindrical rigidity, $\sigma$ - Poisson's ratio, $c_{1}$ - coefficient of elastic foundation for the section where $x_{0} \leq x \leq x_{1}$.

Let us assume that the variable rigidity of the plate to be approximated by the power law

$$
D=D_{0} r^{m}
$$

here $D_{0}, m$ - constants.

Substituting (2) into (1) we get the following equation:

$$
\begin{gathered}
r^{4} \frac{d^{4} w}{d r^{4}}+r^{3}(2 m+2) \frac{d^{3} w}{d r^{3}}+r^{2}(-1+m(1+\sigma)+ \\
\left.+m^{2}\right) \frac{d^{2} w}{d r^{2}}+r\left((1-m)+\sigma\left(m^{2}-m\right)\right) \frac{d w}{d r}- \\
-\frac{c_{1} w}{D_{0} n_{2}} r^{4-m}=\frac{q r^{4-m}}{D_{0}} .
\end{gathered}
$$

The analysis shows when $m=4$ (3) is Euler's equation integrating in elementary functions. However, it is not possible to obtain the solution of (3) in terms of elementary functions when $m \neq 4$. To receive the result we compare the coefficients of (3) with the coefficients of Nielsen's equation [3]:

$$
\begin{gathered}
r^{4} \frac{d^{4} w}{d r^{4}}+A_{3} r^{3} \frac{d^{3} w}{d r^{3}}+A_{2} r^{2} \frac{d^{2} w}{d r^{2}}+A_{1} r \frac{d w}{d r}+ \\
+A_{0} w=0
\end{gathered}
$$

where we have

$$
\begin{gathered}
A_{3}=6-4 a-4 c, \\
A_{2}=2\left(a^{2}-\mu^{2} c^{2}\right)+4(a+c-1)^{2}+4(a-1)(c-1)-1, \\
A_{1}=\left[2\left(\mu^{2} c^{2}-a^{2}\right)-(2 a-1)(2 c-1)\right](2 a+2 c-1), \\
A_{0}=\left(a^{2}-\mu^{2} c^{2}\right)\left(a^{2}+4 a c+4 c^{2}-\mu^{2} c^{2}\right)-b^{4} c^{4} r^{4 c} .
\end{gathered}
$$

The equation (4) is integrated in terms of Bessel functions. When comparing the coefficients of (3) and (4) we determine that the mentioned equations are similar when the following parameter relations are 


$$
\begin{array}{r}
a=m / 4 ; \quad c=(4-m) / 4 ; \mu=-m /(4-m) ; \\
b=\frac{4}{4-m} \sqrt[4]{\frac{c_{1} i}{D_{0}}}, \quad \sigma=\frac{m}{4} .
\end{array}
$$

The solution of axially symmetric problem of a circular plate with varying thickness, resting on an elastic Winkler's foundation, can be written in terms of Bessel functions:

$$
\begin{aligned}
w= & r^{-m / 4}\left[C_{1} J_{\mu}\left(b r^{c} \sqrt{i}\right)+C_{2} Y_{\mu}\left(b r^{c} \sqrt{i}\right)+\right. \\
& \left.+C_{3} I_{\mu}\left(b r^{c} \sqrt{i}\right)+C_{4} K_{\mu}\left(b r^{c} \sqrt{i}\right)\right]
\end{aligned}
$$

The solution (6) can be written in the form:

$$
\begin{aligned}
w= & r^{-m / 4}\left[B_{1} u_{\mu}\left(b r^{c}\right)+B_{2} v_{\mu}\left(b r^{c}\right)+\right. \\
& \left.+B_{3} f_{\mu}\left(b r^{c}\right)+B_{4} g_{\mu}\left(b r^{c}\right)\right]
\end{aligned}
$$

Since the Poisson's ratio for all materials is

$$
0 \leq \sigma \leq 0.5
$$

the above-mentioned solution (7) may be used only for the cases when $0 \leq m \leq 2$. This fact corresponds to the case when the thickness increases in the direction from the inner boundary to the outer one (Figure 1). The stresses are determined by the use of the certain formulae [1]. Further we introduce the dimensionless coordinate $x=b r^{c}$.

\section{THE CALCULATION OF THE OUTER PART OF THE CONSTRUCTION}

We pass to consideration of the outer part of the bottom with the constant thickness. Let us assume that the load caused by the upper part of the structure is subjected along the circumference with the radius $x_{2}$. The plate's thickness when $x=x_{1}$ is continuous and equal to

$$
h=h_{0} x_{1}^{m / 3} \text { when } 0 \leq m \leq 2 .
$$

Here the conditions of the two parts conjugations are fulfilled; the deflections, angles, bending moments, transverse forces remain continuous. We denote the mentioned values respectively as $w_{A}, \vartheta_{A}, M_{A}, Q_{A}$.

The solution of the homogeneous differential equation for axially symmetric bending of the similar plate, resting on elastic foundation, is expressed in terms of Bessel functions [4-7] in the following form:

$$
w=A_{1} u_{0}(x)+A_{2} v_{0}(x)+A_{3} f_{0}(x)+A_{4} g_{0}(x),
$$

where $A_{1}, A_{2}, A_{3}, A_{4}$ - constants;

$$
x=\frac{r}{\ell}, \ell=\sqrt[4]{\frac{D}{c_{2}}},
$$

$c_{2}-$ modulus of the foundation relevant to the outer part.

To write the expression for the plate's elastic surface we introduce the fundamental functions $w_{1}\left(x_{1} ; x\right), w_{2}\left(x_{1} ; x\right), w_{3}\left(x_{1} ; x\right), w_{4}\left(x_{1} ; x\right)$, which properties are described in [1]. We have

$$
\begin{aligned}
& w_{1}\left(x_{1} ; x\right)=\frac{\pi x_{1}}{2}\left[-u_{0}{ }^{\prime}\left(x_{1}\right) g_{0}(x)-v_{0}{ }^{\prime}\left(x_{1}\right) \times\right. \\
& \left.\times f_{0}(x)+f_{0}{ }^{\prime}\left(x_{1}\right) v_{0}(x)+g_{0}{ }^{\prime}\left(x_{1}\right) u_{0}(x)\right], \\
& w_{2}\left(x_{1} ; x\right)=\frac{\pi x_{1}}{2}\left[-u_{0}\left(x_{1}\right) g_{0}(x)-v_{0}\left(x_{1}\right) \times\right. \\
& \left.\times f_{0}(x)+f_{0}\left(x_{1}\right) v_{0}(x)+g_{0}\left(x_{1}\right) u_{0}(x)\right], \\
& w_{3}\left(x_{1} ; x\right)=\frac{\pi x_{1}}{2}\left[u_{0}{ }^{\prime}\left(x_{1}\right) f_{0}(x)-v_{0}{ }^{\prime}\left(x_{1}\right) \times\right. \\
& \left.\times g_{0}(x)-f_{0}{ }^{\prime}\left(x_{1}\right) u_{0}(x)+g_{0}{ }^{\prime}\left(x_{1}\right) v_{0}(x)\right], \\
& w_{4}\left(x_{1} ; x\right)=\frac{\pi x_{1}}{2}\left[u_{0}\left(x_{1}\right) f_{0}(x)-v_{0}\left(x_{1}\right) \times\right. \\
& \left.\quad \times g_{0}(x)-f_{0}\left(x_{1}\right) u_{0}(x)+g_{0}\left(x_{1}\right) v_{0}(x)\right] .
\end{aligned}
$$

Thus, when $x \geq x_{2}$, we can write

$$
\begin{aligned}
& w=w_{\text {II }}=w_{A} w_{1}\left(x_{1} ; x\right)+\vartheta_{A} \ell w_{2}\left(x_{1} ; x\right)- \\
& -M_{A} \ell^{2} w_{3}\left(x_{1} ; x\right)-Q_{A} \ell^{3} w_{4}\left(x_{1} ; x\right) .
\end{aligned}
$$


The influence of the construction upper part can be represented by the moments $M_{2}$ and forces $Q_{2}$ distributed along the circumference with the radius $x_{2}$. Then the expression for the deflections of the combined plate by taking into account the inner and the outer parts is:

$$
\begin{aligned}
w=w_{\mathrm{I}} & +w_{\mathrm{II}}+M_{2} \ell^{2} w_{3}\left(x_{2} ; x\right)+ \\
& +Q_{2} \ell^{3} w_{4}\left(x_{2} ; x\right) .
\end{aligned}
$$

The coefficients incoming in the expression for $w_{\mathrm{I}}$ are determined from the boundary conditions and the conditions of the sections conjugation. The values of modulus of subgrade may be either different or similar.

\section{CONCLUSION}

The analytical method for computation of the combined plate consisting of a few sections with different laws of the thickness variation is proposed. This techniques is stated for the example of the bottom of the cylindrical reservoir examination. The influence of the upper part of the construction under study is considered. The solutions are obtained in the closed form in terms of Bessel functions.

\section{REFERENCES}

1. Koreneva E.B. Analiticheskie Metody Rascheta Plastin Peremennoj Tolschiny i ih Practicheskije Prilozhenija. [Analylical Methods for Calculation of Plates with Varying Thickness and Their Practical Application]. Moscow, ASV, 2009, 238 pages (in Russian).

2. Koreneva E.B., Grosman V.R. Analiticheskoje Reshenije Zadachi ob Izgibe Krugloj Ortotropnoj Plastiny Peremennoj Tolschiny, Lezhazchej na Uprugom Osnovanii. [Analytical Solution of the Flexure of Circular Orthotropic Plate of Variable Thickness, Resting on an Elastic Subgrade].
// Vestnik MGSU, 2011, No. 8, pp. 156-159 (in Russian).

3. Kamke E. Spravochnik po Obyknovennym Differentsialnym Uravneniyam. [The Handbook for Ordinary Differential Equations]. Moscow, Nauka, 1965, 703 pages (in Russian).

4. Korenev B.G. Nekotoryye Zadachi Teorii Uprugosti i Teploprovodnosti, Reshayemyye v Besselevykh Funktsiyakh. [Some Problems of the Theory of Elasticity and Heat Conductivity, Solved in Terms of Bessel Functions]. Moscow, Fizmatgiz, 1960, 458 pages (in Russian).

5. Koreneva E.B. NapryazhennoDeformirovannoje Sostojanie Ledovoj Plity s Polynjej pri Neosesimmetrichnom Zagruzhenii. [Stressed and Strained State of the Ice Slab with the Opening, Subjected to an Action of Unsymmetric Loads]. // Stroitelnaya Mekhanika i Raschet Sooruzhenij, 2016, №5, pp. 13-18 (in Russian).

6. Koreneva E.B. Raschet Beskonechnoj Ledovoj Plity, Oslablennoj Otverstiem. [Calculation of the Infinite Ice Slab, Relaxed by an Opening] // International Journal for Computational Civil and Structural Engineering, 2016, Volume 12, Issue 4, pp. 99102 (in Russian).

7. Koreneva E.B. Metod Kompensirujuschih Nagruzok dlya Reshenija Zadach ob Anizotropnyh Uprugih Sredah. [Method of Compensating Loads for Solving of Anisotropic Medium Problems] // International Journal for Computational Civil and Structural Engineering, 2018, Volume 14, Issue 1, pp. 71-77 (in Russian).

\section{СПИСОК ЛИТЕРАТУРЫ}

1. Коренева Е.Б. Аналитические методы расчета пластин переменной толщины и их практические приложения. - М.: ACB, 2009. - 238 c.

2. Коренева Е.Б., Гросман В.Р. Аналитическое решение задачи об изгибе круг- 
лой ортотропной пластины переменной толщины, лежащей на упругом основании. // Вестник МГСУ, №8, 2011, с. 156159.

3. Камке Э. Справочник по обыкновенным дифференциальным уравнениям. - М.: Наука, 1965. - 703 с.

4. Коренев Б.Г. Некоторые задачи теории упругости и теплопроводности, решаемые в бесселевых функциях. - М.: Физматгиз, 1960. - 458 с.

5. Коренева Е.Б. Напряженнодеформированное состояние ледовой плиты с полыньей при неосесимметричном загружении. // Строительная механика и расчет сооружений, №5, 2016, с. 13-18.

6. Коренева Е.Б. Расчет бесконечной ледовой плиты, ослабленной отверстием. // International Journal for Computational Civil and Structural Engineering, Volume 12, Issue 4, 2016, pp. 99-102.

7. Коренева Е.Б. Метод компенсирующих нагрузок для решения задач об анизотропных средах. // International Journal for Computational Civil and Structural Engineering, Volume 14, Issue 1, 2018, pp. 71-78.

Elena B. Koreneva, Professor, Dr.Sc., Moscow Higher Combined-Arms Command Academy; 2, ul. Golovacheva, Moscow, 109380, Russia, phone: +7(499)175-82-45;

E-mail: elena.koreneva2010@yandex.ru.

Коренева Елена Борисовна, профессор, доктор технических наук, Московское высшее общевойсковое командное орденов Жукова, Ленина и Октябрьской Революции Краснознаменное училище, 109380, Россия, г. Москва, ул. Головачева, д.2, тел.: +7(499)175-82-45; E-mail: elena.koreneva2010@yandex.ru. 